\title{
Properties of Core Ore in Quasi-particle Required for Large Amounts Usage of Limonitic Ores in Iron Ore Sintering Process
}

\author{
Takaho OTOMO, Yasushi TAKASAKI and Takazo KAWAGUCHI ${ }^{11}$ \\ Faculty of Engineering and Resource Science, Akita University, 1-1 Tegata Gakuen-cho, Akita 010-8502 Japan. \\ 1) Corporate Research \& Development Laboratories, Sumitomo Metal Industries, Ltd., 16-1 Oaza-Sunayama, Hasakimachi, \\ Kashima-gun, Ibaraki 314-0255 Japan.
}

(Received on September 1, 2004; accepted on November 30, 2004)

\begin{abstract}
The fluidity of melt formed in the sintering process of iron ores is an important factor for producing a highstrength sinter. When using a large amount usage of limonitic ores as core ore of the quasi-particle of sinter mix, it is predicted that the fluidity of formed melt decreases, because the solid ratio in the melt increases by an acceleration of the assimilation of the core ore with the melt.

In order to control the assimilation of limonitic ore, basic researches were conducted using a modeled briquette, which consisted of a disk-shaped iron ore core and a shell layer of fine mixture composed of $\mathrm{Fe}_{2} \mathrm{O}_{3}$ and $\mathrm{CaCO}_{3}$ reagents. Assimilation rate of various iron ores was measured, and then solid phase ratio in the melt was calculated based on the phase diagram of $\mathrm{CaO}-\mathrm{Fe}_{2} \mathrm{O}_{3}$ system. According to the calculated solid phase ratio in the melt, the fluidity of melt was discussed. The results obtained are summarized as follows:

Fair linear relations were obtained between the porosity of core ore after dehydration and the combined water content of the ore. The assimilation rate of core ore at a specified temperature was represented as a function of the porosity of core ore after dehydration and the holding time at the temperature. The diameter and the apparent density of core ore influenced the calculated solid phase ratio in the melt. It was suggested that an optimal sinter structure was achieved by mixing a large and dense core ore at about 20 mass $\%$ in raw mix.
\end{abstract}

KEY WORDS: iron ore; sintering; iron ore sinter; limonitic ore; assimilation rate; fluidity of melt.

\section{Introduction}

The properties of iron ores imported from Australia, of which volume is more than $50 \%$ of all iron ores used in Japan, have been changing. Limonitic iron ores, such as Marra Mamba type ores and Pisolitic ores, tend to increase because of the shortage of the low phosphorous coarse Brockman type ores, which is the main ores used in Japan. ${ }^{1,2)}$ It is well known that limonitic iron ores contain much combined water, and the fluidity of melt formed in the sintering process using these ores as core ore of quasiparticles decreases by an acceleration of the assimilation of the ore with the melt, because the ores become porous structure due to dehydration of the combined water during sintering. On the other hand, the production of low slag sinter has been required for ensuring permeability in the blast furnace at a high-pulverized coal injection. ${ }^{3)}$ Since it can be predicted readily that both of the large amounts usage of limonitic ores and the decrease in slag constituents of raw materials influence the sintering behavior, it is thought to be necessary to examine about the optimal design of quasiparticles under the situation mentioned above.

The "Research Project for Porous Meso-mosaic Texture Sinter" proposed a new sintering process named MEBIOS (Mosaic EmBedding Iron Ore Sintering). ${ }^{4-6)}$ The purpose of the MEBIOS process is production the sinter having a high quality, high product yield and low slag content under the condition of large amounts usage of limonitic ores by blending two types of raw materials after granulation; i.e. one of them is a large and dense iron ore particle which suppress the assimilation of ore and another is the raw material having a high $\mathrm{CaO}$ composition which promote the formation of melt. However, it is thought to be necessary to examine about the basic properties of limonitic ores such as the assimilation rate in order to determine the size, density and blending ratio of the iron ore particle. Several studies, ${ }^{7-10)}$ which investigated about the assimilation behavior of various iron ores, have indicated that limonitic iron ores assimilate with the melt rapidly. However, quantitative studies concerning to the assimilation rate of various iron ores and to the fluidity of melt are few.

In the present study, the properties of a core ore in quasiparticles of sinter mix required for large amounts usage of limonitic ores and a small slag volume in sintering process of iron ores were investigated by the measurement of the porosity of iron ore after dehydration, the assimilation rate of various iron ores and the solid ratio in formed melt, as the basic study on the suppression of assimilation of limonitic iron ores. 


\section{Experimental}

Hematite Ore A, Marra Mamba type ores $\mathrm{M}, \mathrm{O}$ and L, Pisolitic ore $\mathrm{K}$ and reagents of $\mathrm{Fe}_{2} \mathrm{O}_{3}$ and $\mathrm{CaCO}_{3}$ were used as raw materials in the present experiment. Chemical composition of these ores is listed in Table 1. The content of combined water $(\mathrm{CW})$ represents the loss on ignition after heating at $900^{\circ} \mathrm{C}$ for $1 \mathrm{~h}$ in $\mathrm{N}_{2}$ stream $\left(0.2 \mathrm{~cm}^{3} / \mathrm{min}\right)$. The $\mathrm{CW}$ content is high in the order of ore $\mathrm{A}, \mathrm{M}, \mathrm{O}, \mathrm{L}$ and $\mathrm{K}$. The porosity of these iron ores after dehydration and the assimilation rate of ore were measured. The ore $\mathrm{O}$ was used only to measure the porosity after dehydration.

In the measurement of porosity of the ore after dehydration, the ore sample shaped into a disk $(6 \mathrm{~mm}$ in diameter and $2 \mathrm{~mm}$ in height) by diamond cutter and emery paper was used. In the measurement of assimilation rate of the ore, a modeled briquette consisted of a disk shaped core ore, of which size is the same as that of the ore sample mentioned above, and a shell layer of a mixture of $\mathrm{Fe}_{2} \mathrm{O}_{3}$ and $\mathrm{CaCO}_{3}$ fine reagent was press-shaped into a disk of $10 \mathrm{~mm}$ in diameter and $6 \mathrm{~mm}$ in height at $9.8 \mathrm{MPa}$. The $\mathrm{CaO}$ concentrate of the shell layer was fixed as 20 mass $\%$, which is the eutectic composition in $\mathrm{CaO}-\mathrm{Fe}_{2} \mathrm{O}_{3}$ system. ${ }^{11)}$

Figure 1 shows a schematic diagram of experimental apparatus used in the both of above experiments. A diskshaped ore sample or a briquette was set in a platinum crucible (12 $\mathrm{mm}$ in inner diameter and $10 \mathrm{~mm}$ in height), and then the platinum crucible was set in the quartz crucible (14 $\mathrm{mm}$ in inner diameter and $15 \mathrm{~mm}$ in height). After setting the quartz crucible at the center of infrared furnace, the sample was heated up to a given temperature in air stream $\left(0.5 \mathrm{~N} \mathrm{~cm}^{3} / \mathrm{min}\right)$ at a heating rate of $200^{\circ} \mathrm{C} / \mathrm{min}$. When the temperature of sample was reached to a specified value, the sample was held at the temperature for a given time. After holding at the given temperature, the sample was quenched by blowing cold $\mathrm{He}$ gas $\left(0.02 \mathrm{~N} \mathrm{~m}^{3} / \mathrm{min}\right)$ cooled through liquid nitrogen. The conditions and the analysis methods in each experiment are as follows.

In the measurement of the porosity of the ore after dehydration, the holding temperature was varied at different four levels, i.e., $1200,1250,1300$ and $1350^{\circ} \mathrm{C}$, and the holding time was set to be $0 \mathrm{~min}$. After cooling, the sample was mounted with epoxy-resin and vertically cut at its center. The cut surface was polished. Then, the sample was used for macro-scopic observation and image analysis. In the image analysis, the area fraction of pores existed in the polished plane was measured at a magnification of 200. It was assumed the porosity of ore after dehydration. Furthermore, the diameter of pores larger than $4 \mu \mathrm{m}$ in size was also measured.

In the measurement of the assimilation rate of the ore, the holding temperature was varied at three levels, i.e., 1250,1300 and $1350^{\circ} \mathrm{C}$, and the holding time was varied within 0 to $10 \mathrm{~min}$. After cooling, the sample was treated similar to that of measurement of porosity as mentioned above. Then, the sample was subjected to macro-scopic observation and image analysis. In the image analysis, the area of unassimilated ore was measured at a magnification of 10 . The diameter of equivalent circle of unassimilated ore was calculated from the area of unassimilated ore, and then an equation for calculating the "assimilated amount"
Table 1. Chemical composition and combined water (CW) content of iron ores (mass $\%)$.

\begin{tabular}{|c|c|c|c|c|c|}
\hline Ore & T.Fe & $\mathrm{CaO}$ & $\mathrm{SiO}_{2}$ & $\mathrm{Al}_{2} \mathrm{O}_{3}$ & $\mathrm{CW}$ \\
\hline $\mathrm{A}$ & 67.69 & 0.74 & 0.98 & 2.08 & 1.12 \\
\hline $\mathrm{M}$ & 63.91 & 0.05 & 2.42 & 0.81 & 4.79 \\
\hline $\mathrm{O}$ & 65.08 & 0.01 & 0.86 & 0.34 & 5.79 \\
\hline $\mathrm{L}$ & 62.66 & 0.02 & 1.59 & 0.96 & 7.36 \\
\hline $\mathrm{K}$ & 56.70 & 0.67 & 5.50 & 2.60 & 10.83 \\
\hline
\end{tabular}

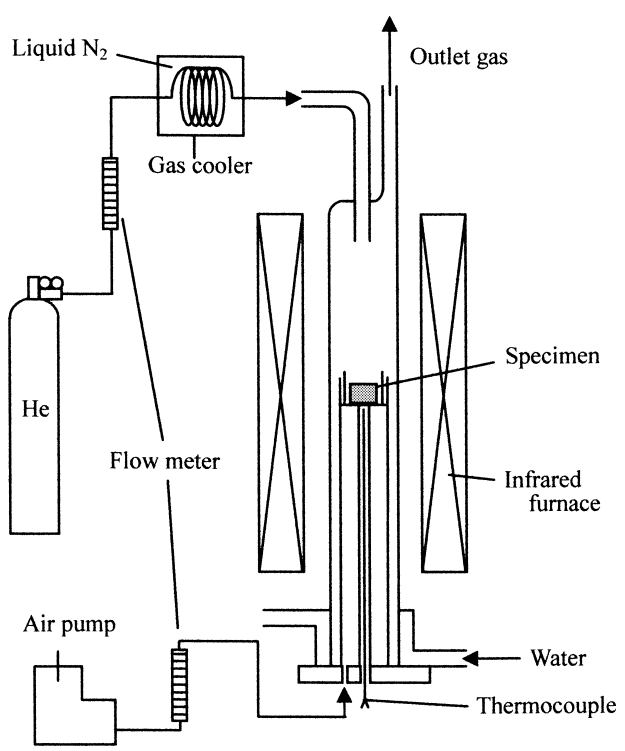

Fig. 1. Schematic diagram of experimental apparatus.

of ore at each temperature was introduced from the changes in the diameter of the equivalent circle of the unassimilated ore. Finally, the solid phase ratio in formed melt was calculated based on the phase diagram of $\mathrm{CaO}-\mathrm{Fe}_{2} \mathrm{O}_{3}$ system ${ }^{11}$ ) from the calculated "assimilated amount" of ore after test. In the calculation, the initial diameter of ore before heating was varied within 2 to $15 \mathrm{~mm}$. According to the calculated results of solid phase ratio in the melt, the fluidity of melt was discussed.

\section{Results and Discussion}

\subsection{Porosity and Pore Diameter of Iron Ore after De- hydration}

Figure 2 shows the pore size distribution of ores A, K and $\mathrm{L}$, which are minimum, maximum and middle in $\mathrm{CW}$ content, respectively, among the ores, after heating up to 1200 and $1350^{\circ} \mathrm{C}$. At the temperature of $1200^{\circ} \mathrm{C}$, the peak is seen at around $0.02 \mathrm{~mm}$ for each ore. The pores of $0.2 \mathrm{~mm}$ or larger exist in ores $\mathrm{L}$ and $\mathrm{K}$. At the temperature of $1350^{\circ} \mathrm{C}$, the peak is seen at around $0.02 \mathrm{~mm}$ similar to the case of $1200^{\circ} \mathrm{C}$. However, large pores over $0.2 \mathrm{~mm}$ were decreased.

Figure 3 shows the relation between heating temperature and the mean diameter of pores observed in ores $\mathrm{A}, \mathrm{K}$ and L. For each temperature, the mean diameter of pores is larger as the $\mathrm{CW}$ content of ore becomes higher. In the ores $\mathrm{L}$ and $\mathrm{K}$, the mean diameter of pores decreases with increasing of the heating temperature. 

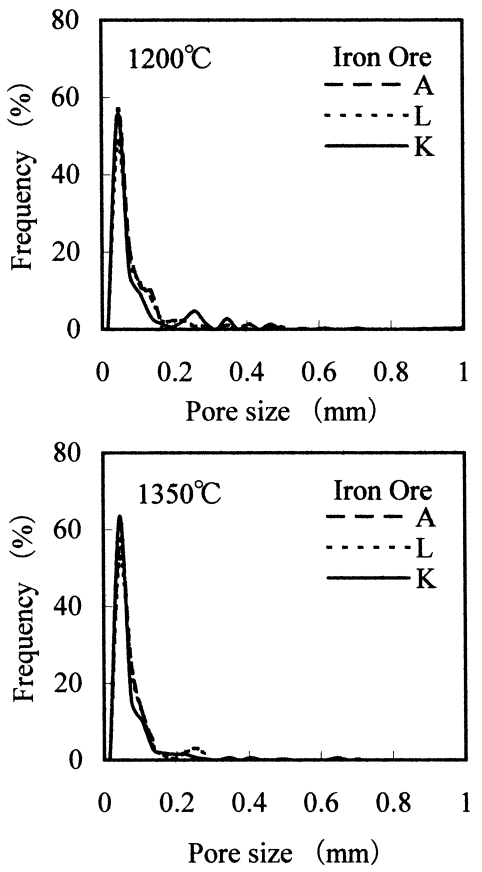

Fig. 2. Size distribution of pores observed by microscopy at a magnification of 200 after heating up to 1200 and $1350^{\circ} \mathrm{C}$.

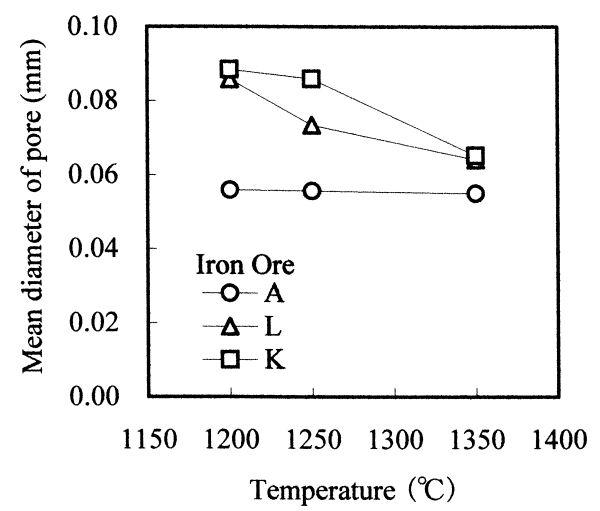

Fig. 3. Relation between heating temperature and mean diameter of pores observed after heating.

Figure 4 shows the relation between $\mathrm{CW}$ content and porosity of ore after heating. The porosity of each ore decreases with increasing in the heating temperature, and the extent is larger as the $\mathrm{CW}$ content of ore becomes higher. On the other hand, a linear relation can be seen between the porosity of ore after heating and the $\mathrm{CW}$ content of ore. Therefore, the porosity after dehydration $\left(P_{\text {temp }}\right)$ at the given temperature can be represented as a function of $\mathrm{CW}$ content of ore as follows.

$$
\begin{aligned}
& P_{1200}=2.80 \mathrm{CW}+7.87 \\
& P_{1250}=2.78 \mathrm{CW}+6.45 \\
& P_{1300}=2.36 \mathrm{CW}+6.35 \\
& P_{1350}=2.03 \mathrm{CW}+5.30
\end{aligned}
$$

\subsection{Assimilation Rate of Iron Ore}

Figure 5 shows the macro-structures of briquettes used ore $\mathrm{L}$ as core ore after holding for a given time at $1300^{\circ} \mathrm{C}$.

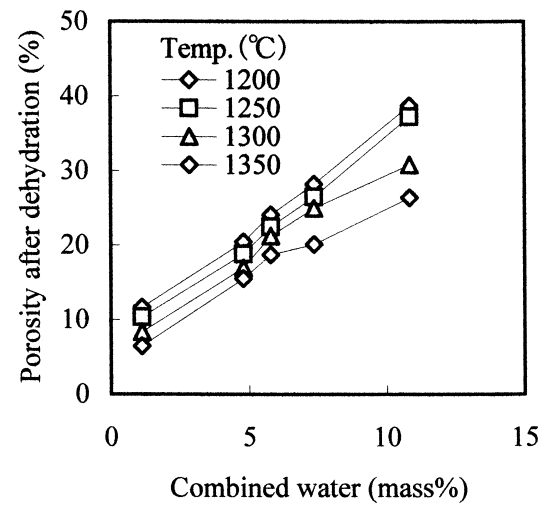

Fig. 4. Relation between combined water content and porosity of ores after dehydration.
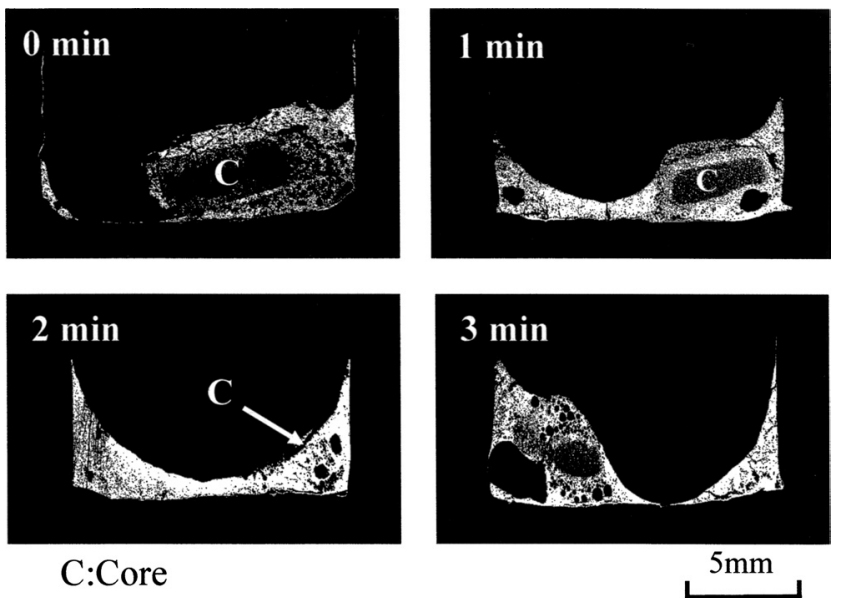

C:Core

$5 \mathrm{~mm}$

Fig. 5. Macro-structure of specimen after heating at $1300^{\circ} \mathrm{C}$. (Core ore: ore $\mathrm{L}$ )

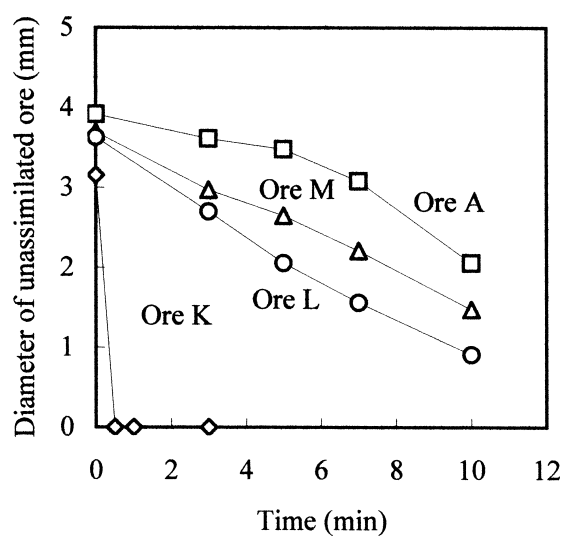

Fig. 6. Changes in diameter of equivalent circle of unassimilated ore at $1250^{\circ} \mathrm{C}$.

The holding time is indicated in figure. At the holding time of $0 \mathrm{~min}$, the relatively large ore (Symbol $\mathrm{C}$ in Fig. 5) can be seen in the sample, and the assimilation of ore with the melt progresses with the passage of time. The ore does not exist after holding for $3 \mathrm{~min}$. It was observed that the extent of assimilation is different with the kind of ore and holding temperature.

Figure 6 shows the diameter of equivalent circle of unassimilated ore in the sample held at $1250^{\circ} \mathrm{C}$. At the holding time of $0 \mathrm{~min}$, it is thought that ore A does not assimilate, since the diameter of equivalent circle is almost the same as 


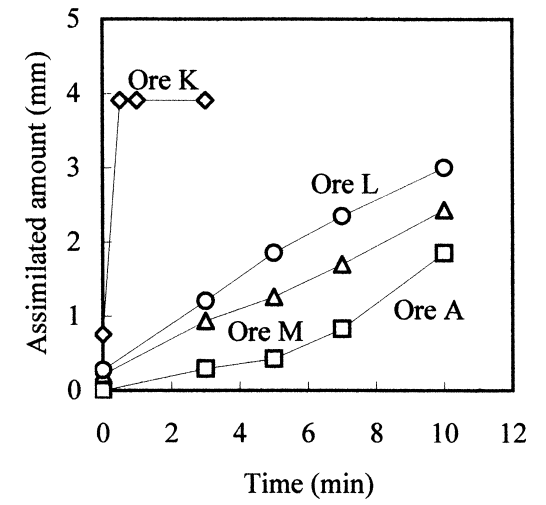

Fig. 7. Changes in assimilated amount of ore at $1250^{\circ} \mathrm{C}$. (Assimilated amount $=3.19$ - equivalent circle diameter of unassimilated core ore $(\mathrm{mm})$ )

that of unheated ore, that is, $3.91 \mathrm{~mm}$. In the case of another ores, it can be said that the assimilation of ore already started before the temperature reached $1250^{\circ} \mathrm{C}$, since the diameter of equivalent circle is small than $3.91 \mathrm{~mm}$. Thus, it can be understood that the assimilation rate becomes larger with increasing of $\mathrm{CW}$ content of ore, as indicated in previous studies. ${ }^{7-10)}$ Furthermore, the diameter of equivalent circle of ore decreases linearly with the passage of holding time for every ore.

Figure 7 shows the "assimilated amount" of ore that is the difference between the diameters of equivalent circle of sample before $(3.91 \mathrm{~mm}$ ) and after heating (shown in Fig. 6). The "assimilated amount" of ore increases linearly with the passage of time for each iron ore. It can be seen that the assimilation of ore K completed after $30 \mathrm{~s}$ as the "assimilated amount" reached $3.91 \mathrm{~mm}$. Moreover, the assimilation rate, i.e., inclination of straight line, becomes larger as the $\mathrm{CW}$ content of ore becomes higher. The "assimilated amount" of ore can be represented as a function of the "assimilated amount" at a holding time of 0 min and the assimilation rate and the holding time, since the "assimilated amount" of each ore changes linearly with holding time.

Figures 8 and 9 show the assimilation rate and the "assimilated amount" of ore at $0 \mathrm{~min}$ obtained from Fig. 7, respectively. Although the sample was held at $1250^{\circ} \mathrm{C}$, the porosity of ore after dehydration was used the value at $1200^{\circ} \mathrm{C}\left(P_{1200}\right)$, because the melt generates at $1205^{\circ} \mathrm{C}$ according to the equilibrium diagram. ${ }^{11)}$ According to Figs. 8 and 9 , the assimilation rate $(y, \mathrm{~mm} / \mathrm{min})$ can be approximated as follows, although there are some problems that measuring points are a few.

$$
y=0.063+0.0075\left(P_{1200}\right)+8.92 \times 10^{-17} \exp \left(P_{1200}\right) \ldots
$$

And the "assimilated amount" at $0 \mathrm{~min}(z, \mathrm{~mm})$ can be approximated as follows.

$$
z=0.027\left(P_{1200}\right)-0.34
$$

Therefore, the "assimilated amount" of ore during holding at $1250^{\circ} \mathrm{C}$ can be represent as a function of $P_{1200}$ and holding time $(t, \mathrm{~min})$ as follows.

$$
\begin{aligned}
& \text { "Assimilated amount" }(\mathrm{mm})_{1250}=\left(0.063+0.0075\left(P_{1200}\right)\right. \\
& \left.+8.92 \times 10^{-17} \exp \left(P_{1200}\right)\right) t+\left(0.027\left(P_{1200}\right)-0.34\right)
\end{aligned}
$$

In the same way, the "assimilated amount" at 1300 and

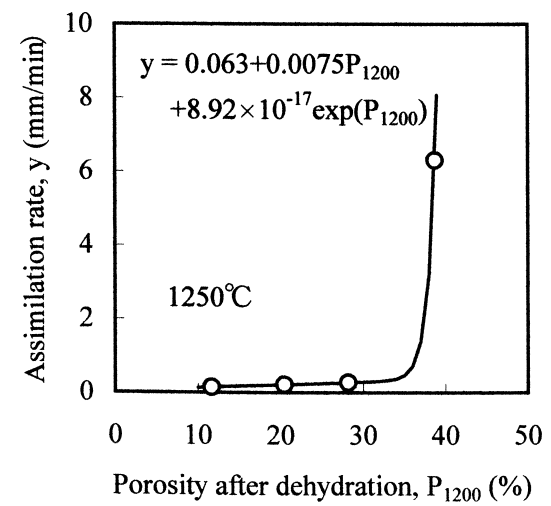

Fig. 8. Relation between porosity of core ore after dehydration at $1200^{\circ} \mathrm{C}$ and assimilation rate at $1250^{\circ} \mathrm{C}$. (Assimilation rate $=($ assimilated amount $) /($ holding time $))$

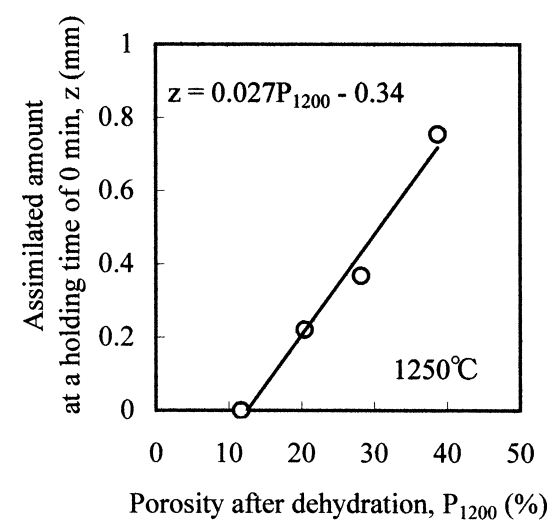

Fig. 9. Relation between porosity of core ore after dehydration at $1200^{\circ} \mathrm{C}$ and assimilated amount at a holding time of $0 \mathrm{~min}$.

$1350^{\circ} \mathrm{C}$ can be represented as follows.

$$
\begin{aligned}
& \text { "Assimilated amount" }(\mathrm{mm})_{1300}=\left(0.89-0.057\left(P_{1200}\right)\right. \\
& \left.+0.021\left(P_{1200}\right)^{2}+3.3 \times 10^{-17} \exp \left(P_{1200}\right)\right) t \\
& +\left(0.065\left(P_{1200}\right)-0.72\right)
\end{aligned}
$$

“Assimilated amount" $(\mathrm{mm})_{1350}=\left(0.056\left(P_{1200}\right)-0.12\right) t$

$$
+\left(0.071\left(P_{1200}\right)+0.42\right) \text {.. }
$$

The "assimilated amount" at $1350^{\circ} \mathrm{C}$ derived by the results of ores $\mathrm{A}$ and $\mathrm{M}$, because ores $\mathrm{L}$ and $\mathrm{K}$ completely assimilated with the melt at a holding time of 0 min.

\subsection{Discussion on the Fluidity of Formed Melt}

After calculation of the "assimilated amount" of the ore based on the Eqs. (7), (8) and (9), the solid phase ratio was calculated on the basis of $\mathrm{CaO}-\mathrm{Fe}_{2} \mathrm{O}_{3}$ phase diagram, ${ }^{11)}$ assuming as follows.

(1) Sample is a duplex type of quasi-particle consisted of a spherical iron ore core and a shell layer of fine mixture. The primary melt forms at the fine mixture with maintaining duplex structure at a high temperature.

(2) The core ore is ore A, M, L or K used in the experiment mentioned above. The impurities in the ore are neglected, namely, $\mathrm{Fe}_{2} \mathrm{O}_{3}$ concentration of the solid part of the ore is 100 mass $\%$. And the solid volume of ore is calculated by $P_{1200}$.

(3) The diameter of core ore is 2, 3, 6, 9, 12 and $15 \mathrm{~mm}$. 

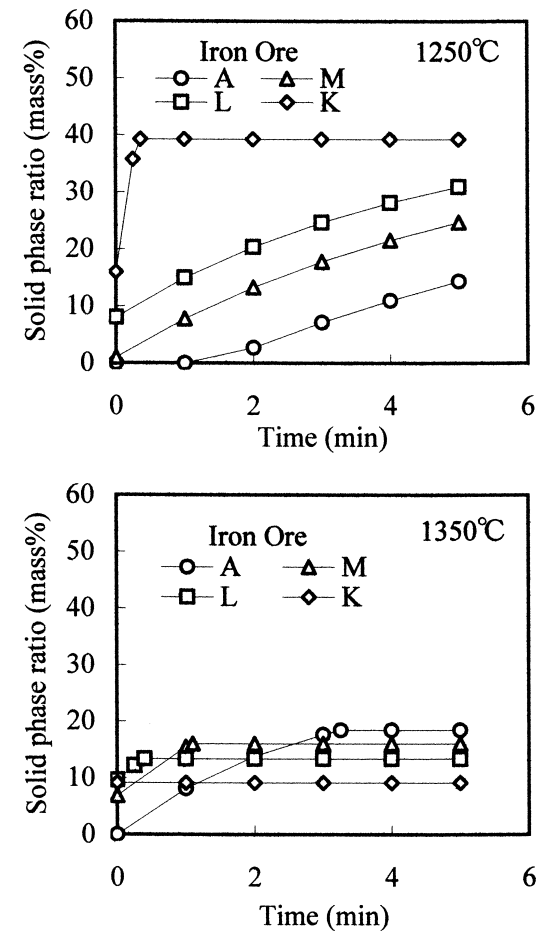

Fig. 10. Changes in calculated solid phase ratio in melt with holding time. (Diameter of core ore: $6 \mathrm{~mm}$ )

(4) The shell layer of the quasi-particle is of $\mathrm{CaO}-\mathrm{Fe}_{2} \mathrm{O}_{3}$ binary system. The $\mathrm{CaO}$ concentration of shell layer is fixed as 20 mass $\%$, which is the eutectic composition in the $\mathrm{CaO}-\mathrm{Fe}_{2} \mathrm{O}_{3}$ system. ${ }^{11)}$

(5) The $\mathrm{CaO}$ concentration of quasi-particle is set as 10 mass $\%$ on the basis after calcination.

(6) The holding temperature is 1250,1300 and $1350^{\circ} \mathrm{C}$, and the holding time is within $5 \mathrm{~min}$.

Furthermore, the apparent density of each ore was calculated based on $P_{1200}$ and the true density of iron ore assumed as $4.8 \mathrm{~g} / \mathrm{cm}^{3}$. As the results, the apparent density of ores $\mathrm{A}, \mathrm{M}, \mathrm{L}$ and $\mathrm{K}$ was estimated as $4.24,3.82,3.45$ and $2.94 \mathrm{~g} / \mathrm{cm}^{3}$, respectively.

Figure 10 shows the calculation results of solid phase ratio in the melt. In Fig. 10, the holding temperature is 1250 and $1350^{\circ} \mathrm{C}$, and the diameter of core ore is $6 \mathrm{~mm}$. In the case of $1250^{\circ} \mathrm{C}$, it can be seen that the solid phase ratio increases with the passage of holding time. In the case of ore $\mathrm{A}$, the solid phase ratio starts to increase after $1 \mathrm{~min}$. It suggests that the $\mathrm{Fe}_{2} \mathrm{O}_{3}$ concentration in the melt reaches the liquidus after $1 \mathrm{~min}$, because the assimilation rate of ore A is basically small. In the case of ores $\mathrm{L}$ and $\mathrm{K}$, the solid phase has already existed at a holding time of $0 \mathrm{~min}$. It suggests that the $\mathrm{Fe}_{2} \mathrm{O}_{3}$ concentration in melt reaches to co-existing state of solid and liquid when temperature reaches $1250^{\circ} \mathrm{C}$. The solid phase ratio becomes larger with increasing of the $\mathrm{CW}$ content of ore, and increases with the passing of holding time except the case of ore K. In the case of ore $\mathrm{K}$, the solid phase ratio becomes constant after $20 \mathrm{~s}$, since the ore assimilates completely at the time. Therefore, the solid phase ratio at a same holding time increases with increasing of the $\mathrm{CW}$ content of ore, because the assimilation rate becomes larger with increasing of the $\mathrm{CW}$ content of ore.

In the case of $1350^{\circ} \mathrm{C}$, the solid phase ratio becomes

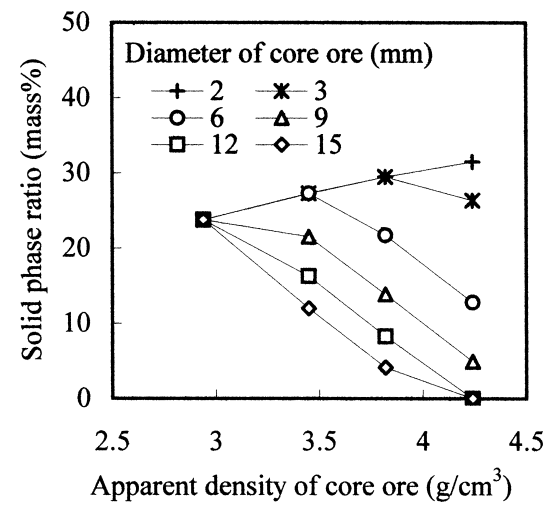

Fig. 11. Relation between apparent density of core ore and calculated solid phase ratio in melt. (Temp: $1300^{\circ} \mathrm{C}$, holding time: $2 \mathrm{~min}$ )

constant after holding for $0,25,60$ and 180 s for ores $\mathrm{K}, \mathrm{L}$, $\mathrm{M}$ and $\mathrm{A}$, respectively, since each ore assimilates completely. The constant value in solid phase ratio becomes smaller with increasing of the $\mathrm{CW}$ content of ore. The reason of this result depends on the decreasing in solid volume of ore possible to move into the melt, since the solid part of ore after dehydration becomes smaller with increasing of the CW content of ore, even if the "assimilated amount" of ore is same. Therefore, it can explain the reason why the melt formed in the sintering process using limonitic ore as core ore of quasi-particles becomes fluid at higher temperature is the decreasing in the solid phase ratio.

Figure 11 shows the relation between the apparent density of ore and solid phase ratio at a holding temperature of $1300^{\circ} \mathrm{C}$ and a holding time of $2 \mathrm{~min}$. In the case of $2 \mathrm{~mm}$ in diameter of core ore, the solid phase ratio increases with increasing the apparent density of ore, because the assimilation is completed within $2 \mathrm{~min}$ for every ore. In the case of 3 and $6 \mathrm{~mm}$ in diameter of core ore, the solid phase ratio first increases, and then decreases over a specified apparent density. In the range below the specified apparent density, the solid phase ratio increased with increasing the apparent density due to the termination of assimilation within $2 \mathrm{~min}$. In the range over the specified apparent density, the solid phase ratio decreased with increasing the apparent density, because the assimilated volume of ore decreased due to the decrease in assimilation rate of ore. In the case over $9 \mathrm{~mm}$ in diameter of core ore, the solid phase ratio decreased with increasing the apparent density, because the assimilated volume of ore decreased due to the decreasing in assimilation rate of ore.

Whereas, assuming the solid phase ratio to be 10 mass $\%$ for maintaining the fluidity of a melt, the diameter of core ore is over $9 \mathrm{~mm}$ at an apparent density of ore of $4.2 \mathrm{~g} / \mathrm{cm}^{3}$ and over $12 \mathrm{~mm}$ at that of $3.8 \mathrm{~g} / \mathrm{cm}^{3}$. When the apparent density of ore is below $3.5 \mathrm{~g} / \mathrm{cm}^{3}$, it is difficult to maintain the fluidity of melt even if the diameter of ore is $15 \mathrm{~mm}$. Therefore, it is thought to be necessary to arrange the large and dense ore particles in raw materials, as well as in MEBIOS process proposed by the "Research Project for Porous Meso-mosaic Texture Sinter". However, it is necessary to consider about the influences of $\mathrm{CaO}$ concentration of shell layer on the assimilation rate of core ore, because these calculations were made based on the equation obtained from the present experiment using the modeled bri- 


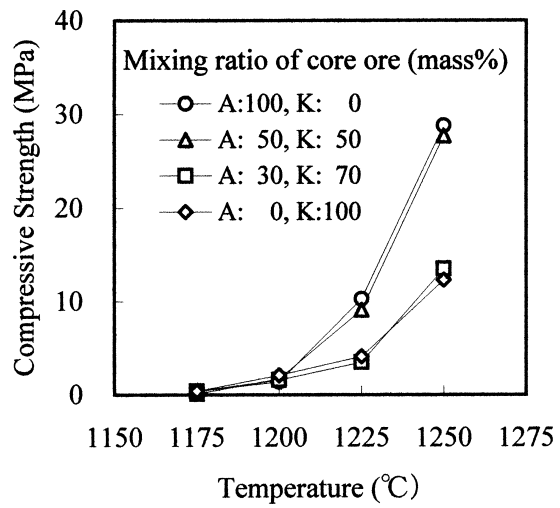

Fig. 12. Changes in compressive strength of packed bed specimen of quasi-particles with heating temperature. ${ }^{12}$ (Core ore: 40 mass $\%, \mathrm{CaO} / \mathrm{SiO}_{2}=2$ )

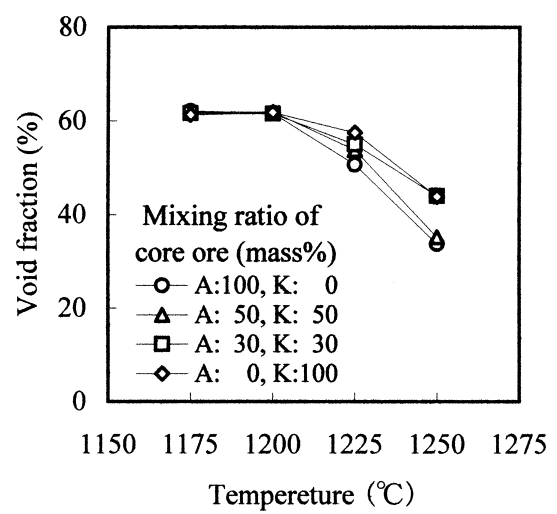

Fig. 13. Changes in void fraction of packed bed specimen of quasi-particles with heating temperature. ${ }^{12)}$ (Core ore: 40 mass $\%, \mathrm{CaO} / \mathrm{SiO}_{2}=2$ )

quette having a shell layer with 20 mass $\%$ of $\mathrm{CaO}$.

The authors have reported the experimental results about the structural change in packed bed of quasi-particles using ores $\mathrm{A}$ and $\mathrm{K}$ of $2 \mathrm{~mm}$ in diameter as core ore. ${ }^{12)}$ In this experiment, the core ore fraction of quasi-particle is 40 mass $\%$ and the basicity $\left(\mathrm{CaO} / \mathrm{SiO}_{2}\right)$ of quasi-particle is constant at 2, i.e., $\mathrm{CaO}$ concentration is fixed at 8 and 10 mass $\%$, using ore $\mathrm{A}$ and $\mathrm{K}$ as core ore, respectively. Figures 12 and 13 show the compressive strength and the void fraction of packed bed of quasi-particles obtained in the previous experiments. ${ }^{12)}$ At $1250^{\circ} \mathrm{C}$, the compressive strength of sintered sample using ore A only as core ore is higher than that of using ore $\mathrm{K}$ only as core ore. And the compressive strength of sintered sample using ore A and $\mathrm{K}$ as core ore in the proportion of $1: 1$ by weight is similar to the result using ore A only as core ore, then the compressive strength of sintered sample using ore $\mathrm{A}$ and $\mathrm{K}$ as core ore in the proportion of $3: 7$ by weight is similar to the re- sult using ore K only as core ore.

On the other hand, the void fraction of sintered sample using ore A only as core ore is smaller than that of using ore $\mathrm{K}$ only as core ore. And the void fraction of sintered sample using ore $\mathrm{A}$ and $\mathrm{K}$ as core ore in the proportion of $1: 1$ by weight is similar with the result using ore A only as core ore, then the void fraction of sintered sample using ore $\mathrm{A}$ and $\mathrm{K}$ as core ore in the proportion of $3: 7$ by weight is similar with the result using ore $\mathrm{K}$ only as core ore. According to these results, it is suggested that the mixing ratio of quasi-particle having 40 mass $\%$ of ore A as core ore is estimated as 50 mass\% for maintaining the preferable sinter structure.

Consequently, it is thought that the preferable sinter structure can be achieved by mixing dense and large iron ores at 20 mass $\%$ of whole sinter mix, because the mixing ratio of quasi-particle having 40 mass $\%$ of dense core ores is 50 mass \%, as mentioned above. Therefore, it is thought to be a subject how to produce the dense and large particles using limonitic iron ore, as indicated by the "Research Project for Porous Meso-mosaic Texture Sinter". ${ }^{6}$ )

\section{Conclusions}

In order to suppress the assimilation of limonitic iron ores, some basic researches, such as the measurement of the porosity of iron ore after dehydration, estimation of the assimilation rate of various iron ores and solid phase ratio in formed melt and structural change in packed bed of quasi-particles, were conducted. As a result, it is confirmed that the preferable sinter structure can be achieved by mixing a dense and large iron ore at the ratio of 20 mass $\%$ in raw mixtures.

\section{REFERENCES}

1) Y. Hida and N. Nosaka: Tetsu-to-Hagané, 78 (1992), 960.

2) T. Inazumi: Energy Resources, 17 (1996), 581.

3) K. Yamaguchi: Bull. Iron Steel Inst. Jpn., 4 (1999), 666.

4) S. Kamarov, E. Kasai, K. Nushiro and M. Nakano: CAMP-ISIJ, 17 (2004), 582.

5) C. Kamijo, M. Matsumura and T. Kawaguchi: CAMP-ISIJ, 17 (2004), 586.

6) T. Usui, T. Kawaguchi, E. Kasai, F. Tsukihashi, M. Nakano, K. Nushiro, Y. Yamagata and K. Yamamoto: CAMP-ISIJ, 17 (2004), 606.

7) S. Sato, T. Kawaguchi, M. Ichidate and M. Yoshinaga: Tetsu-toHagané, 70 (1984), 39.

8) E. Kasai, W. Shengli and Y. Omori: Tetsu-to-Hagané, 77 (1991), 56.

9) Y. Hida, J. Okazaki, K. Ito and S. Hirakawa: Tetsu-to-Hagané, 78 (1992), 59.

10) N. Oyama, K. Nushiro, K. Igawa and K. Sorimachi: Tetsu-toHagané, 83 (1997), 1

11) B. Phillips and A. Muan: J. Am. Ceram. Soc, 41 (1958), 445.

12) T. Otomo and Y. Takasaki: Tetsu-to-Hagané, 89 (2003), 1107. 